\title{
Empowerment of Urban Marginal Community Through Urban Farming: Challenges and Solutions
}

\author{
Bekti Wahyu Utami ${ }^{a^{*}}$, Hanifah Ihsaniyati ${ }^{\mathrm{b}}$ \\ ${ }^{\mathrm{a}, \mathrm{b}}$ Faculty of Agriculture \\ Universitas Sebelas Maret \\ Surakarta, Indonesia \\ *Email: uut_ag@yahoo.com
}

\begin{abstract}
Urban farming is a solution for the environment and urban communities, especially in marginal areas. These solutions include saving the environment by managing waste, improving urban aesthetics, increasing oxygen supply in the city, and increasing income for urban communities. Especially considering waste is a complicated problem in urban areas. If not managed properly, the waste will disturb the aesthetics of the city, a source of pollution, and endanger health. Solo City is inseparable from the waste problem including Kampung Bibis Baru RW 24 Kelurahan Nusukan and Kampung Ngemplak Sutan RW 37 (especially RT 03) Mojosongo Subdistrict, both of which are marginal areas both economically and socially. As the nearest university, Sebelas Maret University felt compelled to contribute in solving the problem. For that purpose, empowerment and facilitation efforts to realize the urban farming are prosperous. Empowerment is done through integrated waste management by fostering community entrepreneurship towards improvement of welfare. On the other hand, the role of the student as a change agent and the next generation is very important. Therefore, this social engineering activity is done by involving students in the KKN (Rural Social Internship Program) Program. Empowerment methods are implemented by combining different approaches, techniques, and types of activities. There are many challenges faced in assisting and empowering marginal people in urban areas. In order for empowerment to continue, it is found and implemented solutions.
\end{abstract}

\section{Keywords: City, Garbage, Prosperous, Empowerment, Solution}

\section{Introduction}

Urban marginalized societies have limitations both economically and socially. Sindu Dwi Hartanto (2011) mentioned that a group of people and individuals whose low income per capita so he entered the poor category, so he entered in the marginal group. Likewise the unemployed, he also belongs to the marginal category. Included in this group are beggars, scavengers, laborers, farmers, and people with mediocre or even inadequate income. This is a marginal sense economically. Societies are said to be socially marginal if the society is unfairly or discriminatively treated by gender, a person or community group experiencing social marginalization, and a society or community whose rights are violated.
The people of Solo City especially Kampung Bibis Baru RW 24 Kelurahan Nusukan and Ngemplak Sutan RW 37 (especially RT 03) Kelurahan Mojosongo is marginal society (marginalized). They are marginalized because most are classified as poor, living on the edge of Kali Anyar, and have low social status. Low social status is indicated by livelihood occupied by odd workers, factory workers, pedicab drivers, some even do the work andActivities that deviate from norms such as pickpocketing, drunkenness and some unlawful marriages "kumpul kebo" (Report of Rural Social Internship Program, 2016). Communities in the area are marginalized both economically and socially.

Bekti Wahyu Utami and Hanifah Ihsaniyati (2017) mentioned that the complicated problem in Kampung Bibis Baru RW 24 Kelurahan Nusukan and Ngemplak Sutan RW 37 (especially RT 03) Kelurahan Mojosongo as well as the problems that often occur in urban areas is the problem of waste. Waste is a source of soil pollutants, disturbing scenery, causes of environmental pollution, and harmful to health. Waste management will produce new useful products that can even increase people's income. In both locations the waste is managed to be organic fertilizer, souvenirs, and other handicraft items. Furthermore, fertilizer produced is used as nutrients for plants to support urban farming.

Urban farming has many benefits, among others: 1) contributes environmental saving through waste management through reuse and recycle concept, 2) helps to create clean city with integrated waste management implementation with principle of $3 \mathrm{R}$ (reuse, reduce, recycle) for waste management , 3) Can produce clean air (oxygen supply) and improve the quality of urban environment, 4) Improving urban aesthetics, 5) Reducing costs by saving transportation and packaging costs, 6) Fresh food at the time of arriving to the urban consumers, 7) Becoming additional income for the townspeople (Novi sanriarambe, 2014)

In addition, urban farming affects the economic, health, social and environmental aspects of the city. With the existence of urban farming there will be benefits of increasing prosperity, justice, togetherness, comfort, quality of life, and environmental sustainability (Mazeereuw, 2005 https://romypradhanaarya.wordpress.com). Enciety (2011) at https://romypradhanaarya.wordpress.com, adding that urban farming contributes to food security, adding to the income of surrounding communities as well as recreational and hobby facilities. 
Urban farming has the potential and opportunities to develop. On the other hand it would be challenging if urban farming was developed in marginalized communities both economically and socially. Limited motivation and partisanship, low knowledge of technological innovation. The low availability of supporting institutions are some of the things that hamper urban farming development. Therefore, it is necessary to empower marginalized communities in urban areas to develop these factors. As the nearest university, Sebelas Maret University was called to be able to contribute positively to the development of urban farming in Solo City.

The marginalized community empowerment in Solo City especially for Bibis Baru RW 24 Kelurahan Nusukan and Ngemplak Sutan RW 37(especially RT 03) Kelurahan Mojosongo focuses on empowering marginal community in urban areas through urban farming. On the other hand, students as part of the campus and as agents of change are worthy to be involved. Therefore, urban marginal community empowerment is done in synergy with the activities of Rural Social Internship Program (Bekti Wahyu Utami and Hanifah Ihsaniyati, 2017)

The urban marginal community empowerment activities in urban farming are full of challenges. However, this should not be ignored and without follow-up. To address these challenges, the empowerment team plans and seeks solutions to continuous and sustainable empowerment activities.

\section{Method}

After previously there was a debriefing activity, students were directly deployed to the location of KKN. This activity requires students to live with the community and participate actively in their activities. This program is implemented with several methods, among others 1) Training: includes a) Training on motivation success, b) Management Training and Waste Management, and c) Training of cultivation of vegetables and fruits by vertikultu, hidroponik, and "tabulampot" Fruit in pots), d) Waste Management entrepreneurship training; 2) Assistance, and 3) Benchmarking

\section{Challenges And The Solution Of Empowering Marginal Society In Urban Farming Activities}

The community at the location of the Rural Social Internship program is marginal both economically and socially. Marginal economically is shown from low income level and classified as poor especially people living on edge of Kali Anyar. Marginal socially in the sense that the community at the program site is in a poor social life as shown by the level of crime and immoral behavior committed by the local community (Report of Integrative Thematic Rural Social Internship Program, 2014)

Accompanying and empowering marginal societies both economically and socially encounters many challenges. They tend to follow new things that have obviously proven successful. They will follow innovations whose results are quickly visible (practical and pragmatic). Indifference to the surrounding environment, especially the river is also still very minimal, indicated by the littering behavior.

During the implementation of this program, some of the challenges facing the team in empowering marginalized communities in Solo City include 1) fostering positive attitudes and successful community motivation, 2) improving the positive attitude and skills of urban marginal people about urban farming, 3) Addressing the Limitations of marginal society's knowledge and Skills on Wastewater Treatment to Support Urban Farming, and 4) plan and maintain urban farming sustainability. To overcome these challenges, steps are taken to ensure that community empowerment continues. The challenges and solutions are presented below:

\section{A. Growing positive attitude and motivation of society success}

The team's main challenge is to foster positive attitudes and successful motivations of marginalized communities in the program locations. A person's behavior is determined by his or her attitude; A positive attitude is expected to give birth to positive behavior as well. Therefore, in order for the expected positive change to materialize, the first thing to do is to change attitudes or shift the marginal society's mindset to the meaning of life, work activities, the keys to success, the environment, and waste issues.

To address these challenges, the first and primary solution taken by the team is training in successful motivation for marginal communities in the program site. The training aims to 1) change the mindset about ultimate success. They will find it easier to have a positive mindset than to think negatively. While positive thoughts provide meaningful value to life will make life even better, 2) Facilitate success. After the successful motivation training, it is hoped that the community in the program location will get a strong impetus to achieve success both in the world and in the hereafter, so it will leave the forbidden things including immoral act as done so far, 3) improve performance. With successful motivation training will arise inner spirit to work harder, 4) Developing the potential that exists. After participating in the motivation seminar, it is hoped that the community can develop the existing potential in their environment with all the creativity to achieve economic prosperity.

This training is more like a debriefing of motivation, awaken the sleeping lion in every self, awaken the awareness of life and the fighting spirit to achieve success. For that, the speaker (source) prepared by the team is a very competent to go to the above four goals. This training speaker is a powerful professional motivator who is also an ustadz, dalang, entrepreneur, and teacher. In addition, for the community to feel comfortable and ready for the training is done at the location of the partners agreed that is the Kelurahan Nusukan Sub District Banjarsari Solo City. Training time is also an agreed time and allows residents to be present at night. This training received appreciation and enthusiasm of citizens as evidenced by the number of citizens present and the enthusiasm of the residents during the event. This is done by the empowerment team by remembering the marginal community in the location of the program is the adult that should be the process of learning also in accordance with the characteristics of adult education 
Adult learning processes have characteristics such as: 1) empowerment activities need to take into account the characteristics of adults, who have generally experienced "deterioration" of the senses (sight, hearing), and capture / reasoning; Emotional characteristics of adults, who are usually more sensitive, irritable, do not want to be patronized, feel more experienced and 2) place and time of implementation activities tailored to community agreement (Mardikanto, 2007).

Urban farming activities introduced in this program are the cultivation of vegetable and fruit crops with vertikultur, hidroponik, and "tabulampot" (fruit in pot). Cultivation of vegetables and fruits with the three techniques are done among others to provide vegetables and fruits for the family, maintain the freshness of the environment, improve the environmental aesthetics. The three techniques are also done because of limited land owned by citizens.

Innovation of vegetable and fruit cultivation with vertikultur, hidroponik, and "tabulampot" technique is very attractive especially for the urban communities who have limited land as in the location of the program. However, there are limited knowledge and also skills of the community in the location of the program about the innovation of the three techniques of cultivation of vegetable and fruit crops. On the other hand, economically as well as socially they have limitations. To that end, the challenge facing the empowerment team is to improve the positive attitude and skills of the urban marginal community about the urban farming activities.

The solution to the above challenges is with intensive mentoring and training. Intensive assistance in vertikultur activities starts from what has been owned by the community so that people have a positive attitude toward this innovation. In addition, assistance is done by involving the community actively in the activities. This activity begins with the community collecting used bottles in the community and arranging them into a series of vertikultur. In addition to saving costs, the use of used bottles also helps increase the usefulness of plastic waste. After that decorated with paint, then filled with planting media and plant seeds. The ready-made vertikultur series are then distributed to the villagers to inspire them to grow with narrow land, making the environment greener and beautiful. In addition to vertikultur, the utilization of open space that is still in the location of the program is also used to make mini demonstration garden filled with various kinds of plants, both fruit crops, vegetable plants, spices and ornamental plants.

Training was conducted to improve community skills on vertical, hydroponic, and tambulampot buddaya techniques. The resource persons of the training are students of KKN program that bring innovation from the campus to the community. Training activities include preparation of materials, preparation and installation of vertikultur installations, preparation and installation of hydroponic type Nutrient Film Technique (NFT) installations. The community actively participates in this activity. Funds are also not only sourced from students but also through self-help communities. Catfish ponds made to provide hydroponic nutrition are donations from the residents. In addition, the community also participated in the provision of fruit plant seedlings for Tabulampot and its pots.
Participation is a process whereby all parties can shape and engage in all development initiatives. In a development dimension, participation is a keyword that is believed to be an essential tool. Participation as a goal is defined as supporting people and articulating and negotiating their interests at the social, institutional and polici making levels in the partner country (syahyuti, 2014). In this activity there is a participatory development approach that engages the community actively in all substantial decisions regarding them.

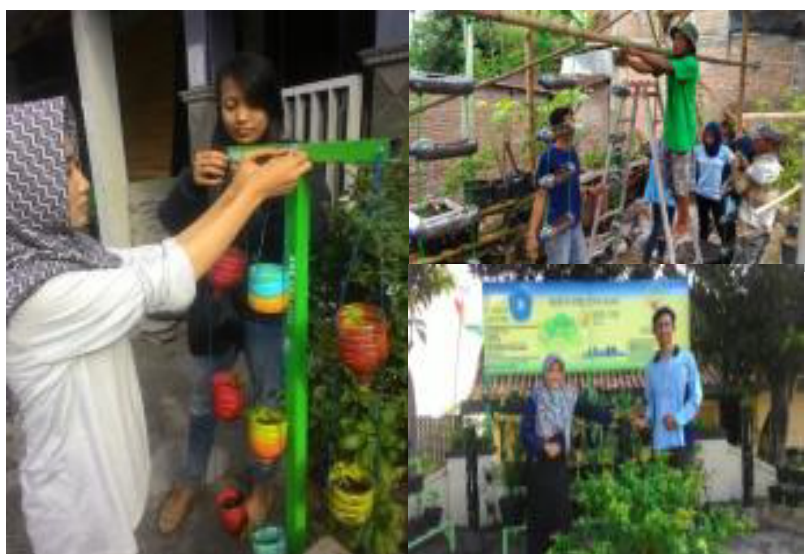

Figure 1.Vertikulture creation by joint team of Community and Vegetable and Vegetable Pilot Garden at Program Location

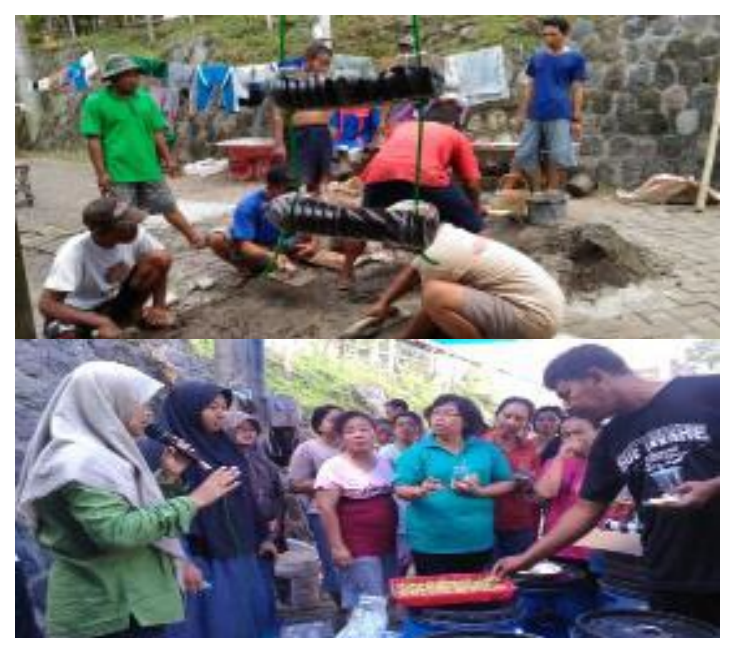

Figure 2. Production of Verticulture and Hydroponics of Vegetables and Fruits by a joint team of the Community

Another thing that must be considered in the implementation of innovative training of urban farming activities is the process of training or innovation achievement should be submitted as an adult education process (andragogie). Andragogie is meant for the positive attitude of the community to the team, resource persons, and also the innovation that is delivered increases. Especially considering that people in the program location are adults ..

Other characteristics of the adult education process are 1) teaching and learning process going on laterally / horizontally, as a participatory learning process in which all involved sharing / exchanging information, knowledge, and experience 2) the informant's position is neither above nor Higher than the participant, but in an equal position, 3 ) the role of resource person is not as a teacher who must 
patronize the community, but merely as a facilitator who helps the learning process, 4) the materials or innovation given must depart from the "felt need" of the community, 5 ) the place of learning should not be settled, But can move in accordance with the material and opportunities, 6) the success of the learning process, not measured by how much transfer of knowledge, but more attention to the farreaching dialogue (discussion, sharing) between the community with the source (Mardikanto, 2007).

The urban farming activities that include vertikultur, hidroponik and "tabulampot" as well as integrated waste management provided to the partner community are carried out with the six approaches to the above characteristics of adult education approach. Where the training was conducted not with a patronizing attitude, both the resource person and the KKN team did not feel the most know but regarded the community have the same ability only they did not understand yet. In order to make the learning process more effective place of study was made to move even also through method of anjangsana / benchmarking where partner community is invited to study in place which have same activity and have succeeded to do it. This will certainly provide a separate motivation for learners to be successful as what he saw.

\section{B. Addressing the Limitations of Urban Marginal Knowledge and Skills on Household Waste \\ Management to Support Urban Farming}

In addition to being managed as a Garbage Bank, the garbage at the program site is recycled to be a high value souvenir. In addition, to support the most important urban farming, the waste is processed into fertilizer

Community knowledge and skills about fertilizer innovation from household waste / waste is still very limited. Educational background and experience are the factors that influence. In addition, some people still like to throw garbage in the river where it shows the motivation of society that still low in managing garbage. Low motivation is also a fundamental thing that needs to get a solution. In addition, marginal urban communities in the program locations tend to be critical and not easily adopt innovations if there is no evidence. The low motivation, knowledge, and community skills for household waste treatment innovation as well as their unique character are the challenges facing the team in their empowerment efforts.

The solution that is done is training the processing of household waste into organic fertilizer to support urban farming. Training was conducted to overcome the limited knowledge and skills of the community about the processing of household waste. Innovation delivered in the training is the processing of individual household waste into liquid organic fertilizer and waste processing communally into solid organic fertilizer. Individual household waste treatment allows the community to conduct their own at home post training. Communal waste processing can also continue the community as a source of income group.

Given the uniqueness of the marginal community in the program location, the training is carried out with various approaches and principles. The approach used in the training of household waste treatment is the individual and group approach. Individual approach is done to provide information and motivation motivation intensively to people who experience kesuliitan. On the other hand, the group approach is done during the delivery of training materials by resource persons

Training is also done by remembering some principles of learning. The first principle held by the team is the effect principle. The things done by the team and the resource persons are to first show the goals and benefits that the community will get after training. Mardikanto (2007) states that learning outcomes will be better when the learning process (included in the training) will provide something beneficial to the citizens of learning, or give something that is liked or make people learn to enjoy it.

Mardikanto (2007) also mentioned that the innovations submitted to the community should give high hopes to the beneficiary community, that the innovation: can be implemented and succeeded well, providing interesting economic and non economic benefits acceptable to sociocultural values local.

Therefore, in order to obtain a complete practical knowledge then the solution is to present a competent speaker and has proven successful in processing household waste (both household and communal) into fertilizer. In addition, the speaker who was presented is a figure who has been successful also to market the fertilizer that has been produced.

In addition, to add experience and demonstrate the success of urban farming and waste processing into fertilizers and other products; The community was invited to the benchmark to the successful garbage bank group "Rukun Santoso" in Klaten Regency.

Another challenge is that people at the program site are people who work during the day and do not have much free time, whereas on the other hand their knowledge and skills about processing household waste into fertilizer is very limited. The solution to this challenge is household waste treatment training carried out with group approaches and direct practice techniques.

To answer the above challenges, the team is based on the second principle of practice principle. Training with hands-on practice will improve understanding and save time. Mardikanto (2007) describes the principle of practice (practice) as a learning process coupled with exercise, or physical activity to further stimulate the activities of the body (legs, hands, etc.), or learn while doing activities experienced by the learners themselves. The principle of practice, based on the understanding that learning outcomes will be better when people learn to have practice experience. Nevertheless, it should be remembered that the activities of training and repetition of the activity should not be excessive resulting in over-saturation (over learning) which would actually be able to reduce the quality of learning achievement.

In this activity used anjangsana communication method combined with field trip, thus the relationship of resource persons with the client occurs directly. The method of anjangsana is a visitation method that is carried out by making a good visit at home / residence (anjangsana) or in place they used to do daily activities (anjangkarya). While the field trip method is an approach where the target is invited to visit certain objects that have been planned / selected. In field trips, empowerment activities are accompanied by entertaining the target (the partner community). In the field trip activities, the participants are stimulated to observe, interview, exchange ideas, practice 
certain skills, or gain experience. In order to cultivate imagination and stimulate creative thinking in his target, based on his experiences of representing, working, and self-help in trying new activities he has never experienced and done (Mardikanto 1993)

It is expected that after the training, the community can be inspired by the spirit to be more concerned about the environment and utilize household waste to be used as organic fertilizer. Organic fertilizer produced by household scale will be used as a fertilizer of vegetables and fruits that are managed by the community in the household, to meet the food needs. In addition, in the future organic fertilizers managed communally can be developed as a source of group income.

C. Planning and maintaining urban farming sustainability

Community empowerment is to increase capability and increase community self-reliance. In the practice of community empowerment conducted by many parties, it is often limited to economic empowerment in the context of poverty alleviation (poverty reduction). Therefore, community empowerment activities are always carried out in the form of productive activity development for income generation (income generating). Such understanding is not wrong, but not enough. Because the essence of community empowerment is to improve the ability, to encourage the will and courage, and to provide opportunities for the local (community) efforts to with or without external support to develop their independence for the sustainable improvement of welfare (economic, social, physical and mental) Mardikanto, 2007).

To that end, the arrival of the team faced by the team is to plan and maintain the sustainability of urban farming conducted by the community in the location of the program. Urban farming is expected to continue even though the KKN program has been completed. For that it needs to be planned and the community needs to be prepared in order to keep implementing urban farming activities even though the empowerment team and KKN students are not in the program location. The community must be prepared for independence and remain committed to continue the urban farming activities that have been introduced. Their forms of independence include caring for crops from vertikultur, hydroponic, and tabulampot cultivation; Still processing household waste into fertilizer; And still have a positive attitude and motivation to try.

The team's solution to this challenge is 1) to maintain good relations with the community even when the program is officially completed 2) provide incentives in the form of appropriate technology for compost bin for household waste and composter building to be managed communally, And 3) facilitate entrepreneurship training and business network expansion.

\section{Conclusion and Recommendation}

With this devotional activity is certainly one of the efforts of universities to take part in its role as a center of innovation, dissemination and transfer of technology / knowledge. For the community this activity actually makes the motivation to live more quality, both from social aspect and economy. So when it is realized then there is or no aid they continue to carry on activities that are positive and provide benefits for them and the community does not become dependent / karitatif but can be independent to be empowered.

\section{References}

[1] Arya, R.P.2011. Pertanian Dalam Kota (Urban Farming).https://romypradhanaarya.wordpress.com. Accessed on July 15th, 2017.

[2] Hartanto,S.D.2011. Siapa Kelompok Marjinal? https://sinduhartanto.wordpress.com. Accessed on July 24th, 2017.

[3] Mardikanto, T. 2007. Sistem Penyuluhan Pertanian. Sukoharjo: PUSPA.

[4] ------------------, 1993.Penyuluhan Pembangunan Pertanian. Surakarta. UNS Press.

[5] Novi sanriarambe. 2014. Konsep Urban Farming (Pertanian perkotaan).http://novisanriarambe.blogspot.co.id, accessed June 15th 2017.

[6] Syahyuti, 2014. Mau Ini Apa Itu? Komparasi Konsep, Teori dan Pendekatan dalam Pembangunan Pertaniandan Pedesaan (125 versus 125). PT Nagakusuma Media Kreatif (Amplitudo Media Science).East Jakarta.

[7] Utami, Bekti Wahyu, 2014. Laporan KKN Tematik Kelurahan Nusukan dan Kelurahan Mojosongo: Pengentasan Kemiskinan. Universitas Sebelas Maret. Surakarta. Unpublished.

[8] Utami, B.W dan Hanifah I. 2017. Empowering Urban Society Dengan Rekayasa Social Melalui Manajemen Pengolahan Sampah Terpadu Untuk Pelestarian Lingkungan Dan Pertanian Perkotaan Sebagai Upaya Pengentasan Kemiskinan Daerah Marjinal. Dikti Field Project Report of 2016.

[9] . 2017. Empowering Urban Society Dengan Rekayasa Sosial :Upaya Menuju Pengentasan Kemiskinan Daerah Marjinal. Proceeding of National Seminar; Pemberdayaan Masyarakat Fakultas Pertanian of UPN Veteran Yogyakarta.Yogyakarta :Pascasarjana UPN Yogyakarya. 